\title{
Scientific Literacy Ability Enhancement in Applying Appgeyser Web Learning Media of Sparkol Video Scribe During the Covid-19 Pandemic
}

\author{
Umi Pratiwi ${ }^{1, *}$ Siska Desy Fatmaryanti ${ }^{1}$ Eko Setyadi Kurniawan ${ }^{1}$ Raden Wakhid
}

\author{
Akhdinirwanto $^{1}$ \\ ${ }^{1}$ Physics Education, Muhammadiyah University of Purworejo, 54111, Indonesia \\ ${ }^{*}$ Corresponding author.Email: umipratiwi@umpwr.ac.id
}

\begin{abstract}
Online learning and learning literacy during the Covid 19 pandemic is very important and very necessary. Online Learning through smartphones is the leading media for students in the Learning and teaching process. Therefore, learning physics material for optical tools requires the use of interesting and effective online media by implementing Android-based learning media through web Appgeyser learning media of Sparkol Videoscribe to enhancement students' scientific literacy skills. This attempt is examined by a study using a quasi-experimental method pre-experimental design approach, which is one group pretest-posttest design using eleventh grade High school as the sample. The result shows that students happened to increase their scientific literacy skills up to $43.4 \%$. , particularly on the ability understanding the concept of optical instruments categorized as "good." The use of a modified Appsgeyser web media learning of Sparkol Videoscribe media that is more attractive allows to significantly increase the ability of science processing.
\end{abstract}

Keywords: Scientific Literacy Ability, Appgeyser Web, The Covid-19 Pandemic.

\section{INTRODUCTION}

Technology continues to evolve and plays an essential role in global competition. Quality human resources are very supportive in this competency era. Quality human resources are very supportive in this competency era. The personal competencies needed today are related to personal abilities in the use of information and communication technology, which is better known as the era of digitalization in the era of the industrial revolution 4.0 [1]. The period of the digital industry, also known as the era of automation, requires people who have 21 st-century competence to be able to compete and be creative. An individual will be able to compete when he/she can master information technology, media and literary information mastery [2]. Understanding digital or automation technology has become something that should be in the era of the industrial revolution 4.0. The period of information technology will be dominated by the digitalization of technology [3]. This phenomenon is likely to affect and worldwide in the world of education in terms of the use of information and communication technology in the teaching and learning process in schools [4].

The rapid development of the world of technology must be balanced with the ability to read, write, describe, and design something with the ability to think critically which causes a person to communicate effectively and efficiently so as to create meaning in his world [5]. This ability is known as scientific literacy and literacy skills if it is associated with applying mastery of concepts and processes to everyday life [6]. Scientific literacy skills are needed in the current era because of the large number of new learning media used in the learning process so that students are required to develop their literacy skills [7][8][9]. Learning science, especially physics, will find it easier to achieve meaningful learning goals if students are able to develop literacy skills, especially scientific literacy to solve the problems at hand [10][11]. The important point of scientific literacy ability is closely related to the scientific thinking ability of students in using their knowledge and the scientific process that is passed in understanding a phenomenon so that they are able to make decisions or conclusions to solve problems [12] [13]. 
The ability of scientific literacy is greatly supported by the existence of school facilities in providing infrastructure. Much has happened in several schools in Purworejo district, especially schools in rural areas, the low ability of scientific literacy is due to the fact that teaching materials still use the education office output textbooks and power points with teacher-centred learning models [14]. The results of our team's observations, $80 \%$ of teachers still use power points and only $20 \%$ use textbooks. The results of surveys and interviews with sample schools resulted in $32 \%$ of students who diligently brought textbooks, and the rest only listened to the teacher's explanation. Students admitted that they were excited to read textbooks, only about $20 \%$, meaning that almost $80 \%$ of students stated that they were not interested in reading and studying textbooks. Students are not excited to read textbooks, where it appears that students who carry textbooks only partially, thus hindering the learning process. With the existence of a Powerpoint, it is indeed quite helpful in learning for teachers, but some students are less clear that students are less enthusiastic in Learning, especially learning physics which is full of formula equations. The textbooks provided by the school have monotonous and less dynamic content, so that students are less interested or not interested. The low interest in reading and studying manual textbooks results in low literacy skills of students, especially the ability to read and learn material sources [15][16]. Therefore, it is necessary to have solutions and new breakthroughs to overcome these problems by adjusting the technological developments available around the students' environment as a learning resource [17][18]. One of the uses of media that is easily accessible to students is a smartphone.

Smartphones, which were previously only used for communication, can now be used for academic purposes such as learning resources [19]. Smartphone technology is also quite developed to make it easier for students to access information without being limited by space and time. Now, what is being developed with an Androidbased mobile operating system makes it easy and practical to be used wherever it is [20]. Android-based learning media using smartphones is the right choice for distance learning under current conditions. One of them is learning media web appgeyser based on sparkol video scribe, which is practical and makes it easy for students to bring and help teachers in delivering interesting and interactive learning materials [21]. Appsgeyser is a free web platform that allows converting any web content into an Android application and has three applications to help people pour their ideas into an Android application. Media web appgeyser is integrated with

Sparkol Video Scribe is an animated video learning medium consisting of a series of images arranged into a complete video. This software has unique characteristics that are able to present learning content by combining images, sound and designs that attract students [22]. The features provided by this application are very diverse so that they can become a learning medium that can be tailored to the desired material or content. This study applies Appsgeyser learning media integrated with Sparkol Video Scribe to improve scientific literacy skills in optical materials.

\section{METHOD}

This research is an experimental research using a quantitative approach supported by a descriptive qualitative method. The research design applied is quasiexperiment [23] with pre-experimental of Pretestposttest one group design depicted in Table 1 [24][23] shown in Table $1 . \mathrm{O}_{1}$ a beginning test before being given treatment, $\mathrm{X}$ refers to Learning using the Appgeyser sparcol video scribe and $\mathrm{O}_{2}$ is the last test after being given treatment.

Table 1. One Group Pre-test - Post-test design.

\begin{tabular}{|l|l|l|}
\hline Pre-test & Treatment & Post-test \\
\hline$O_{1}$ & $X$ & $O_{2}$ \\
\hline
\end{tabular}

The first test done before the experiment (O1) is called pre-test, while the last test after the experiment $(\mathrm{O} 2)$ is called post-test, and the effect of treatment or experiment was done between (O1) and (O2) [24]. Treatment in this research refers to the Implementation of Appgeyser learning media using Sparcol Video Scribe. Table 2 Indicators of scientific literacy skills [25].

Table 2. Indicators of scientific literacy with three aspects

\begin{tabular}{|l|l|c|c|}
\hline $\begin{array}{l}\text { Aspects of Science } \\
\text { Literacy }\end{array}$ & \multicolumn{1}{c|}{ Indicator } & $\begin{array}{l}\text { Number } \\
\text { Items }\end{array}$ & $\begin{array}{l}\text { Question } \\
\text { Number }\end{array}$ \\
\hline Science concepts & 1. Understand an optical instrument concept & 1 & 1 \\
\hline & 2. Using optical instrument equations & 2 & 2 and 5 \\
\hline Science process & 3. Analyze scientific questions on optical instruments & 1 & 3 \\
\hline & $\begin{array}{l}\text { 4. Making conclusions from investigations into optical } \\
\text { instrument materials }\end{array}$ & 2 & 4 and 6 \\
\hline $\begin{array}{l}\text { Situation and realm of } \\
\text { application }\end{array}$ & $\begin{array}{l}\text { 5. Apply the concept of optical instruments and explain } \\
\text { the functions of optical instruments in everyday life }\end{array}$ & 1 & 7 \\
\hline
\end{tabular}


In the initial research test, the researcher guided students to fill out a questionnaire to find out their initial ability about scientific literacy skills and their understanding of optical instrument material. The aspects of literacy skills are the Science process, and the situation and realm of application-the final test (post-test) Applying Learning Media Web Appgeyser from Sparkol Videoscribe. Learning is carried out 3 (three) times pre- test and three times post-test. The stages of implementing the research are presented in Figure 1.

In the final test (post-test) students apply the Appgeyser learning media using the Sparcol Video Scribe to compare scientific literacy skills with the pretest results. In this second stage, a post-test was carried out with an assessment of scientific literacy skills, according to Arikunto [26] with scoring as in Table 3.

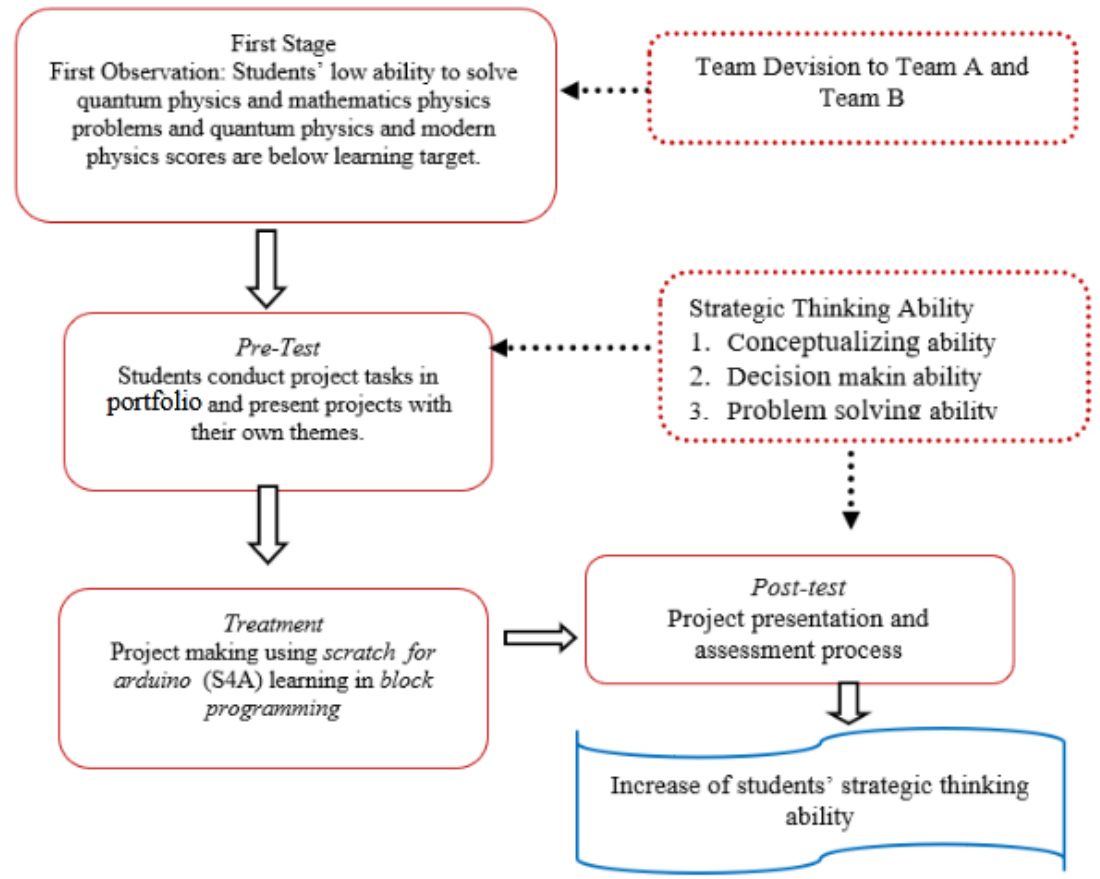

Figure 1 The learning stages in Appgeyser media use the Sparcol Video Scribe to improve scientific literacy skills

Table 3. Category of Science Literacy Skills Assessment Score

\begin{tabular}{ll} 
Scor & Interpretation \\
\hline$\leq 60$ & Failed \\
$61-65$ & Less \\
$66-70$ & Enough \\
$71-75$ & Good \\
$>75$ & Very Good \\
\hline
\end{tabular}

\section{RESULT AND DISCUSSION}

\subsection{Presenting the Results}

Learning physics material optical tools class XI IPA by implementing the Apgeyser learning media using Android-based Sparcol Video Scribe has been implemented with significant results. The Appgeyser display in which there is a learning video from the Sparkol video scribe can be seen in Figure 2.

Android-based learning media using smartphones such as Appgeyser web media integrates with Sparkol Video Scribe to make learning more interactive. Students can access learning material anywhere and anytime. The primary two-way communication between teachers and students is done through Google Classroom (GC). Meanwhile, learning materials are accessed via an Android smartphone by installing the appgeyser application from the Play Store. After the Appgeyser application is installed on an Android smartphone, students can learn and access learning material in accordance with the assignments and instructions given by the teacher in GC.

Scientific literacy skills are known for conducting pre-test and post-test. Each question consists of seven questions with a grid of indicators for aspects of scientific literacy skills which are listed in Table 2. The results of 
the students' assessment scores before and after treatment can be seen in Table 4. The pre-test and post-test assessments consist of seven questions. Scientific literacy skills.
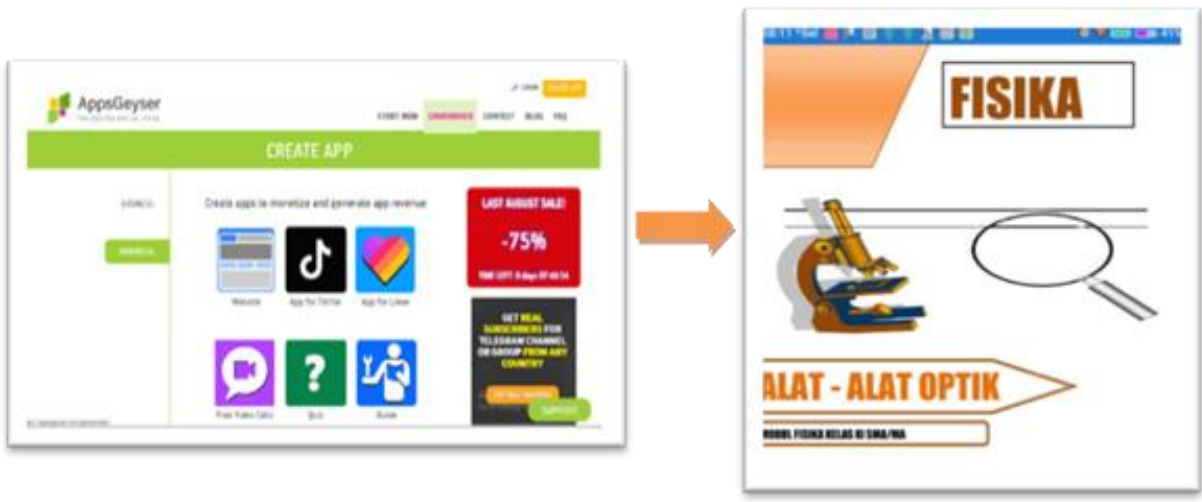

Figure 2 Appgeyser learning media display using Sparcol Video Scribe Optical Tools material

Tabel 4. Result of recapitulation pre-test and the post-test score of literacy sains ability

\begin{tabular}{|c|c|c|c|c|c|c|c|}
\hline & \multicolumn{4}{|c|}{ Science Literacy Indicators } & \multirow{2}{*}{ Average Score } & $\begin{array}{l}\text { Science Literacy } \\
\text { Score }\end{array}$ \\
\hline & 1 & 2 & 3 & 4 & 5 & & 46.02 \\
\hline Pre-test & 14.28 & 6.00 & 9.20 & 7.54 & 9.00 & 59.56 & 66.00 \\
\hline Post-test & 18.8 & 12.52 & 10.00 & 10.00 & 14.68 & 88.52 & 56.01 \\
\hline Average & 16.54 & 9.26 & 9.6 & 8.77 & 11.84 & 74.04 & 5 \\
\hline
\end{tabular}

The following are examples of students' answers to the second and fifth questions, which include the second indicator of scientific literacy skills in Figure 3.

The study, which was attended by 25 students, resulted in 5 scores for the assessment of scientific literacy skills consisting of 5 indicators. Each student gets a pre-test and post-test assessment score of scientific literacy abilities. These results can be seen in Figure 4.

The graphic image in Figure 5 below shows the pretest and post-test scores of the 25 students' scientific literacy abilities. The five aspects of scientific literacy skills from the test results (pre-test and post-test) are categorized into four categories, as in Table 2.

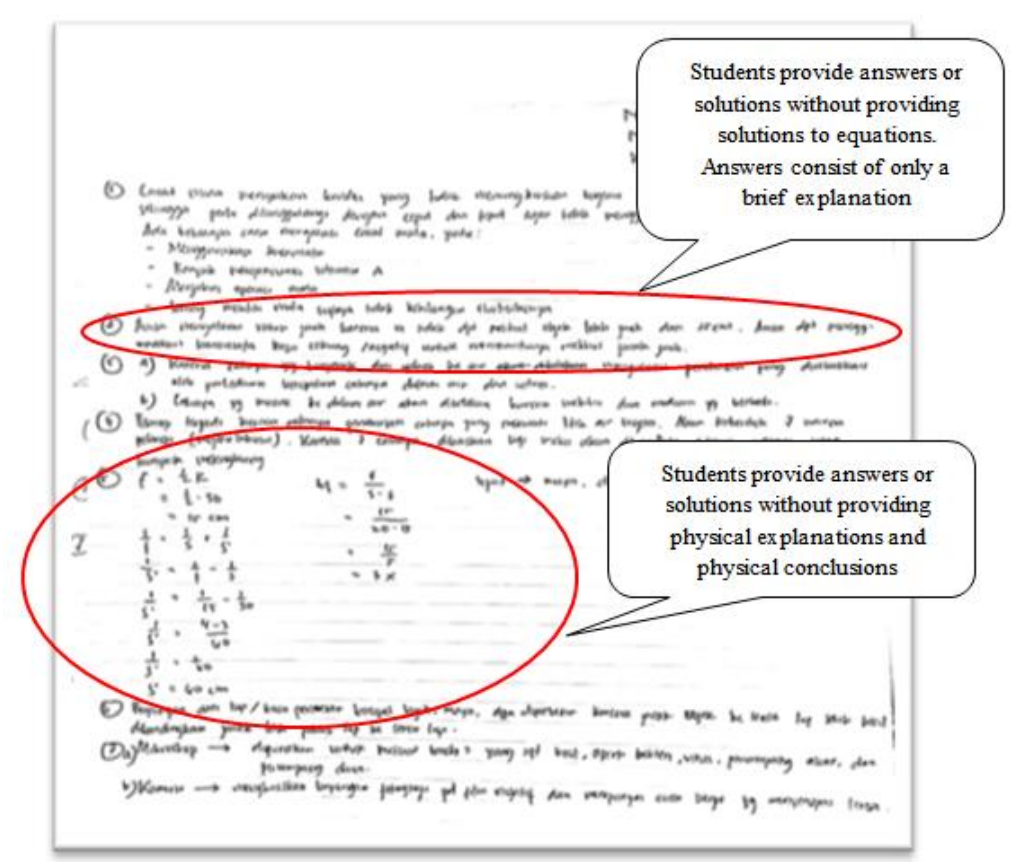

Figure 3 Examples of students' answers in providing solutions to test questions 


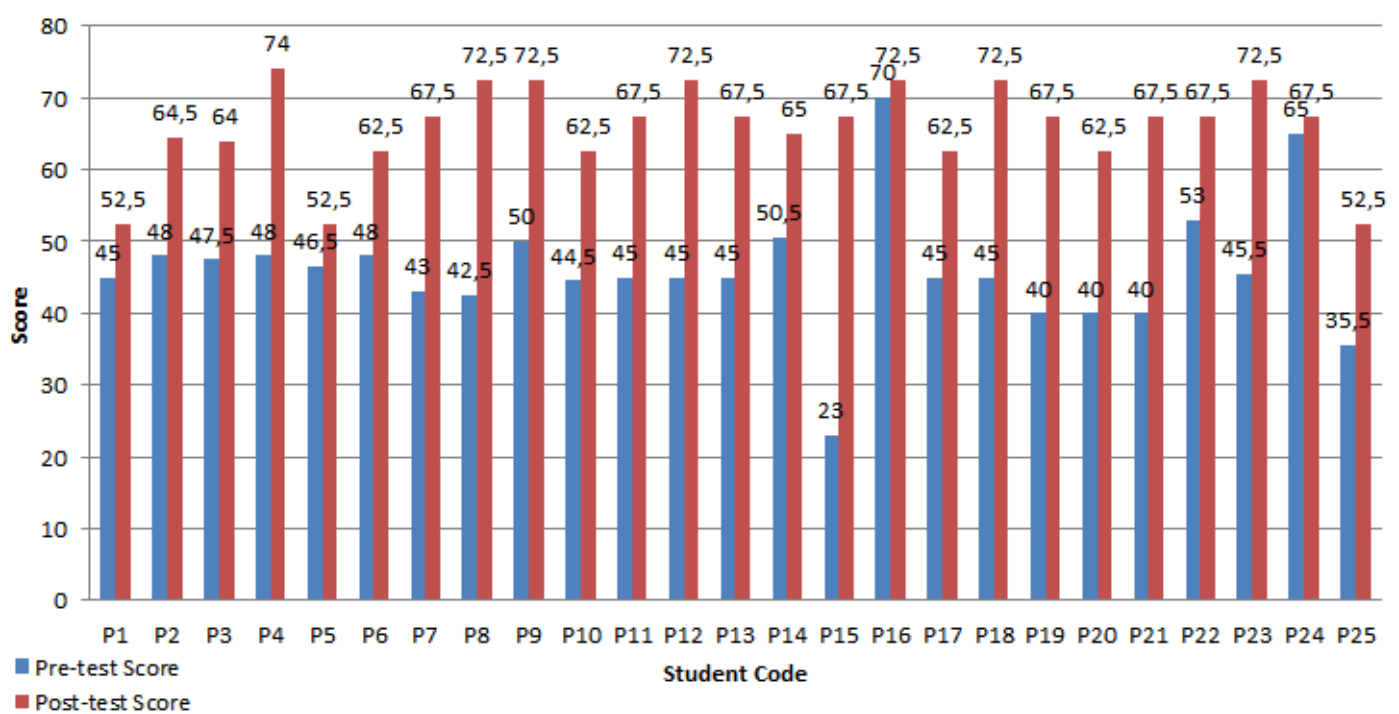

Figure 4 Graph of the science literacy ability assessment score of each student

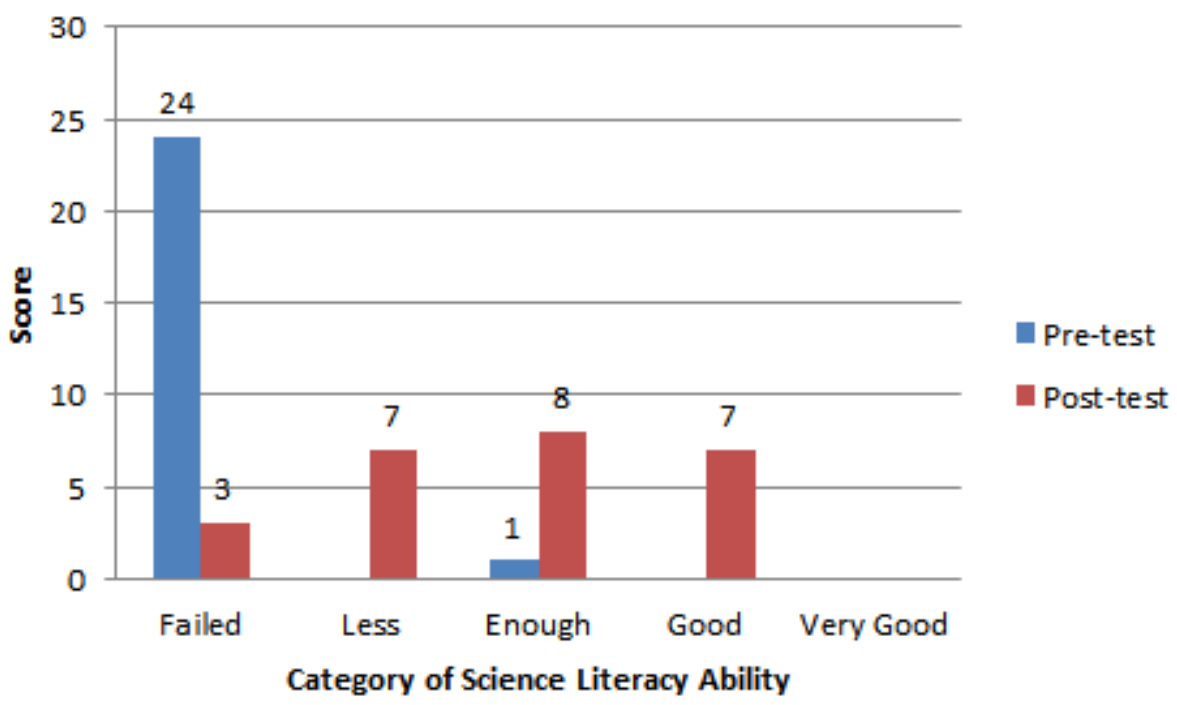

Figure 5 Graph of the pre-test and post-test score category of scientific literacy skills

\subsection{Create a Discussion}

Based on the research data above, Table 4 shows the results of the students' assessment before using Appgeyser or conventional media after using Appgeyser media. The table also describes the results of students' scientific literacy skills with five indicators. The pre-test results resulted in a score of scientific literacy ability of an average of 46.02 in the Failed category. The lowest pre-test assessment score is on the second indicator, with a score of 6.00 out of 20.00 total score or about $30 \%$ of the total score. Students have not been able to use the equations of optical instruments when faced with optical instrument problems. This second indicator contains two questions about solving application questions and calculating the magnification of the image.
Figure 3 shows the solutions given by students during the pre-test; students tend to provide simple solutions without providing a basic solution. The second and fifth questions are included in the second indicator assessment as the ability to use optical instrument equations on a problem. The inability of students to apply the equations of optical tools shows that students have not mastered the material provided in Learning. This pre-test score uses conventional static learning media, and there is no dynamic interaction, causing students to be less enthusiastic in learning material [20].

Figure 4 shows the score for the assessment of scientific literacy skills which consists of 5 indicators. The results of the assessment of scientific literacy skills during the pre-test almost resulted in $80 \%$ of scores below the score of 60. It can be said that Learning before the implementation of Appgeyser learning media using 
Sparcol Video Scribe has not succeeded according to the learning objectives. At the time of the pre-test after treatment, there was a significant increase in the literacy ability assessment score with the highest score of 74 in the Good category. This shows that the implementation of Appgeyser learning media using Sparcol Video Scribe is quite successful in increasing the enthusiasm of students in improving scientific literacy skills.

The pre-test score for the assessment of scientific literacy in Figure 5 resulted in 24 students with the failed category and only 1 student who had enough value. The results of this pre-test score resulted in $96 \%$ in the failed category and only $4 \%$ in the Enough category with a value above 66 from a scale of 100 . This failure was influenced by the existence of learning resources that were not interactive or static; students only relied on learning resources from textbooks and powerpoint materials. In addition, the most influential factor is the situation and conditions of distance learning with an online system during the Covid 19 epidemic. The communication media between teachers and students is only via smartphones so that students experience burnout.

The post-test score for the assessment of scientific literacy skills has increased significantly. There was a decrease in the score for the failed category by $84 \%$ to $28 \%$ in the less category, $32 \%$ in enough category, and $28 \%$ in the good category. The post-test score changes with the application of the Appgeyser Sparcol Video Scribe media provided a reasonably good chance in scientific literacy skills [27]. There are seven students who score in the good category. The good category score ranges from 71 to 75 , with a scale of 100 . It is hoped that this interactive and dynamic learning media will help students to continue learning even with distance learning and be able to improve their scientific literacy skills.

\section{CONCLUSION}

The scientific literacy of students has been enhanced by the application of learning media based on the Android Appgeyser using the Sparcol Video Scribe in class XI IPA material on optical tools. This effort resulted in an increase in scientific literacy skills with an increase of $43.4 \%$. The highest increase occurred in the second indicator regarding scientific concepts, namely the ability of students to apply the equations of optical tools to questions of daily life applications. Before the application of Android-based learning media Appgeyser using Sparcol Video Scribe, the score for the assessment of science literacy skills in the Failed category was almost $80 \%$. On the other hand, after Appgeyser androidbased learning media using Sparcol Video, Scribe achieved a Good category score. Students are more interested and excited about interactive and dynamic learning media.

\section{ACKNOWLEDGMENT}

Thank you to the research institute and community service UMP (Muhammadiyah University of Purworejo) who have helped and monitored this research as a followup to the research of novice lecturers. Thank you to the research team who helped collect data in partner schools.

\section{REFERENCES}

[1] L. Rohida, "Pengaruh era revolusi industri 4.0 terhadap kompetensi sumber daya manusia," J. Manaj. Dan Bisnis Indones., vol. 6, no. 1, pp. 114 136, 2018.

[2] F. Kalelioglu and Y. Gülbahar, "The Effects of Teaching Programming via Scratch on Problem Solving Skills: A Discussion from Learners' Perspective.," Informatics Educ., vol. 13, no. 1, pp. 33-50, 2014.

[3] K. Grzybowska and A. Łupicka, "Key competencies for Industry 4.0," Econ. Manag. Innov., vol. 1, no. 1, pp. 250-253, 2017.

[4] R. Sujanem, I. Suswandi, and P. Yasa, "Pemanfaatan Media Pembelajaran Fisika Berbasis Android Bagi Guru-Guru Fisika SMA," Int. J. Community Serv. Learn., vol. 3, no. 4, pp. 279-289, 2019.

[5] S. V. Drew and J. Thomas, "Secondary science teachers' implementation of CCSS and NGSS literacy practices: a survey study," Read. Writ., vol. 31, no. 2, pp. 267-291, 2018.

[6] V. H. Kaya and D. Elster, "German Students' Environmental Literacy in Science Education Based on PISA Data.," Sci. Educ. Int., vol. 29, no. 2, pp. 75-87, 2018.

[7] D. Ardianto and B. Rubini, "Comparison of students' scientific literacy in integrated science learning through model of guided discovery and problem based learning," J. Pendidik. IPA Indones. vol. 5, no. 1, pp. 31-37, 2016.

[8] G. E. DeBoer, "Scientific literacy: Another look at its historical and contemporary meanings and its relationship to science education reform," J. Res. Sci. Teach. Off. J. Natl. Assoc. Res. Sci. Teach., vol. 37, no. 6, pp. 582-601, 2000.

[9] C. O. Nja, "Scientific literacy of undergraduate Science Education students in the University ofCalabar Cross River State Nigeria."

[10] H. Zakiya, P. Sinaga, and I. Hamidah, "The effectiveness of multi modal representation text books to improve student's scientific literacy of senior high school students," in AIP Conference Proceedings, 2017, vol. 1848, no. 1, p. 50001. 
[11] G. E. Putri and F. Festiyed, “Analisis Karakteristik Peserta Didik dalam Pembelajaran Fisika untuk Pengembangan Buku Digital (e-book) Fisika SMA Berbasis Model Discovery Learning," J. Penelit. Pembelajaran Fis., vol. 5, no. 2, 2019.

[12] R. Bybee and B. McCrae, "Scientific literacy and student attitudes: Perspectives from PISA 2006 science," Int. J. Sci. Educ., vol. 33, no. 1, pp. 7-26, 2011.

[13] R. F. Setyaningtyas, S. Sarwanto, and B. A. Prayitno, "Pengembangan Modul IPA Berbasis Guided Discovery Untuk Meningkatkan Literasi Sains," Fkip E-Proceeding, vol. 3, no. 1, pp. 328334, 2018.

[14] M. A. J. Almasiih, "Pemanfaatan Media Pembelajaran Geografi Pada Siswa Kelas Xii Ips Semester Gasal SMA Negeri 1 Sragi Kabupaten Pekalongan Tahun Ajaran 2016/2017." Universitas Negeri Semarang, 2017.

[15] www.purworejokab.go.id, Pentingnya Empat Hal Pendidikan Karakter. 2019.

[16] S. Desy Fatmaryanti, “Attainment of students' conception in magnetic fields by using of direct observation and symbolic language ability," in Journal of Physics Conference Series, 2017, vol. 909, no. 1, p. 12058.

[17] M. S. Al-Rsa'i, "Promoting Scientific Literacy by Using ICT in Science Teaching.," Int. Educ. Stud., vol. 6, no. 9, pp. 175-186, 2013.

[18] U. Pratiwi and D. Nanto, "Students' Strategic Thinking Ability Enhancement in Applying Scratch for Arduino of Block Programming in Computational Physics Lecture," J. Penelit. Pengemb. Pendidik. Fis., vol. 5, no. 2, pp. 193-202, 2019.

[19] L. Nulhakim, I. Istiqomah, and A. Saefullah, "The influence of using Sparkol videoscribe's learning media to increase science literacy on pressure concept," in AIP Conference Proceedings, 2019, vol. 2169, no. 1, p. 20003.

[20] A. Bartel, P. Figas, and G. Hagel, "Mobile gamebased learning in university education," Educ. Dialog Constr. Mean. Build. Knowl. with dialogic Technol. Amsterdam Benjamins, pp. 159-180, 2014.

[21] N. Rickard, H.-A. Arjmand, D. Bakker, and E. Seabrook, "Development of a mobile phone app to support self-monitoring of emotional well-being: a mental health digital innovation," JMIR Ment. Heal., vol. 3, no. 4, p. e49, 2016.

[22] J. Beer, "Using Online Video Scribed Animation to Teach Writing Self-regulation.” 2012.

[23] H. Darmadi, “Azwar, S.(2011). Metode Penelitian. Yogyakarta: Pustaka Pelajar. Azwar, S.(2012). Penyusunan Skala Psikologi. Edisi 2. Yogyakarta: Pustaka Pelajar."

[24] S. Arikunto, "Metodelogi penelitian," Yogyakarta Bina Aksara, 2006.

[25] H. Galková and K. Kotul'áková, “Rozvíjanie prírodovednej gramotnosti žiakov $\mathrm{v}$ tematickom celku Premeny látok s využitím IBSE.," Biológia, Ekológia, Chémia, vol. 23, no. 1, 2019.

[26] A. Malik, V. Vitriani, and M. M. Chusni, 'Improving Students' Critical-Thinking Skills Through Student Facilitator and Explaining Model in Momentum and Impulse Topic," J. Penelit. Pengemb. Pendidik. Fis., vol. 4, no. 2, pp. 55-64, 2018.

[27] Y. Ramma, A. Bholoa, M. Watts, and P. S. Nadal, "Teaching and learning physics using technology: Making a case for the affective domain," Educ. Inq., vol. 9, no. 2, pp. 210-236, 2018. 